\title{
Research-based language learning through framing analysis as an effort to change the culture of learning
}

\author{
Suharyo* \\ Faculty of Humanities, Diponegoro University, Semarang 50275, Indonesia
}

\begin{abstract}
This research aims to change the culture of listening to a culture of communication/speaking in teaching and learning activities in the classroom because so far, students tend to be passive and lectures go in one way. Besides that, lectures are intended so that students can think and speak critically. For that, a number of models of learning that allows students to think and communicate critically are applied. In addition to that, learning a research-based language is also applied in the lecture. In this study, the analysis of Pan Kosicki's framing model was taken as its approach. The methods are (1) the application of a number of models of learning (discovery, inquiry, focus group discussions, and problem-based) on the learning activities and (2) take the coverage of the contestation of Jokowi and Prabowo which are published in the media viva.com and tribunes.com as examples of research cases. The results are (1) has occurred a change of culture, namely from culture to listening into culture of communication, (2) a method of learning discovery and inquiry as well as FGD are models of learning which are considered effective, (4) there are a number of students who wrote the thesis by using analysis of framing, and (5) the media tend to be less objective in reporting.
\end{abstract}

Keywords: language learning, based on research, framing analysis

\section{Introduction}

All this time, the process of learning, especially in universities, is emphasizing more on aspects of cognitive and affective. Even if there is one, the aspects of psychomotor are not maximally implemented. Because of that, this research is working maximally so that students have the reasoning power and critical power in responding to the phenomenon of social, especially the phenomenon of language. In addition, linguistic learning has so far been more emphasized on aspects of language structures and or systems. All of that is not included in aspects of how languages are used in society[1].

\footnotetext{
* Corresponding author : haryo.sastra@gmail.com
} 
Seeing these symptoms (learning methods and learning substance), the writer is interested in doing this research. This research was conducted to inspire students to be more critical and capable of seeing linguistic phenomena. In addition to that, the students were directed to come out of the "comfy zone".

In practice learning which is offered to students (in-class/lectures on language research methods), there is a number of learning methods in order to find learning models that are considered suitable to explore the courage, skills, and creativity of students in the teachinglearning process. Students are also offered an unfamiliar language analysis model, namely framing analysis.[2]

\section{Research Method}

This research is taking the source of the data of two media online (tribune.com and viva.com) which contains news contestation of Jokowi and Prabowo in the election of the president in 2019 (as an example of the case study as a learning material). The collection of data is done with methods that refer to technical notes, structured interviews, and in-depth interviews[3]. Then, the data are analyzed by framing analysis of Pan and Kosicki[4]. In addition, the students are given material in a number of learning methods. It is done to change the culture of listening to culture of speaking/communication critically. The researcher also actively involved a number of students who (mainly) planned to take up their research topic on framing analysis.

\section{Results and Discussion}

\subsection{Result}

From a number of learning methods that were tested, found methods that are considered effective to change the culture of learning for students. The change of culture which was originally learned through a culture of listening and tends to be passive to a culture of thinking, speaking, expressing opinions, and arguing specifically for application to research-based learning. Learning methods that can change the learning culture are (a) discovery methods, (b) inquiry methods, (c) focus group discussions, and (d) problembased learning methods. Of the four methods mentioned, the result of the example case of the news candidacy Jokowi and Prabowo as a candidate for president 2019 - 2024 with the analysis of framing are then presented in the table below. The result of linguistic research using framing analysis are briefly presented in Table 1 below. 
Table 1. Framing Analysis of Joko Widodo-Prabowo Subianto's Nomination

\begin{tabular}{|c|c|c|c|c|c|}
\hline Topics & $\begin{array}{c}\text { News } \\
\text { Text }\end{array}$ & Syntax & Script & Thematic & Rhetorical \\
\hline \multirow[t]{2}{*}{$\begin{array}{l}\text { Portions } \\
\text { Ma'Ruf in } \\
\text { the debate } \\
\text { of the } \\
\text { presidential } \\
\text { election } \\
2019\end{array}$} & 1 & $\begin{array}{l}\text { Facts of the } \\
\text { response of } \\
\text { Jusuf Kalla } \\
\text { (JK) related } \\
\text { to Ma'Ruf } \\
\text { in Debate } \\
\text { Prime of the } \\
\text { presidential } \\
\text { election in } \\
2019 \text { made } \\
\text { headlines. }\end{array}$ & $\begin{array}{l}\text { The what } \\
\text { and who } \\
\text { elements } \\
\text { stand } \\
\text { out. }\end{array}$ & $\begin{array}{l}\text { The } \\
\text { complete } \\
\text { outline of } \\
\text { the } \\
\text { paragraph } \\
\text { discusses } \\
\text { the case of } \\
\text { Jusuf Kalla } \\
\text { who } \\
\text { believes it is } \\
\text { reasonable } \\
\text { if Ma'Ruf as } \\
\text { the } \\
\text { candidate of } \\
\text { vice } \\
\text { president in } \\
2019 \text { was } \\
\text { not talking } \\
\text { much in the } \\
\text { debate of } \\
\text { presidential } \\
\text { election } \\
\text { which was } \\
\text { held on the } \\
17 \text { January } \\
2019 \text {. }\end{array}$ & Use of JK photos. \\
\hline & 2 & $\begin{array}{l}\text { Facts about } \\
\text { Ma'Ruf who } \\
\text { was not } \\
\text { talking } \\
\text { much in the } \\
\text { debate of } \\
\text { the } \\
\text { Presidential } \\
\text { Election } \\
2019 \text { are } \\
\text { made } \\
\text { headlines. }\end{array}$ & $\begin{array}{l}\text { The what } \\
\text { and who } \\
\text { elements } \\
\text { stand } \\
\text { out. }\end{array}$ & $\begin{array}{l}\text { The } \\
\text { complete } \\
\text { outline of } \\
\text { the } \\
\text { paragraph } \\
\text { discusses } \\
\text { the case of } \\
\text { Ma'Ruf who } \\
\text { speaks less } \\
\text { than Jokowi } \\
\text { in the } \\
\text { debate of } \\
\text { the } \\
\text { Presidential } \\
\text { Election in } \\
\text { 2019. }\end{array}$ & $\begin{array}{l}\text { a) Uses photos of } \\
\text { Jokowi- } \\
\text { Ma'Ruf and } \\
\text { Prabowo- } \\
\text { Sandi. } \\
\text { b) The } \\
\text { prominence } \\
\text { of words that } \\
\text { confirm that } \\
\text { Jokowi } \\
\text { speaks more } \\
\text { than Ma'ruf. }\end{array}$ \\
\hline
\end{tabular}

Discussion. From the analysis of the data above, apparently, the media cannot be the revealer of the reality of the objective as expected the positivistic, as stated by Masnur Muslich [5]. Besides that, this study has resulted in changes in the attitude of the students 
towards the practice of learning, namely (which so far) are in the culture of listening to the culture of communication/speaking actively and critically. It was visible from most of the students by using an analysis of framing for material preparation of the thesis. In addition, in this study found a number of effective learning models that change the paradigm and learning culture, which initially tends to be passive and "only" listening to be active, creative, and dynamic. Models of learning are discovery, inquiry, and problem-based learning, as well as the focus group discussion.

Based on the results of research by using framing analysis from Pan Kosicki[6], it can be concluded: (1) highlighting the syntactic element that is through headlines, (2) the protrusion of the script element that is the focus of the news, (3) the protrusion of the thematic element that is through the development of a comprehensive paragraph, (4) the protrusion of the rhetorical element, namely the photo. The addition of photos to the text message that was written by the journalist aims to provide an illustration of events. In addition to that, in terms of alignments: viva.co.id shows an attitude that tends to be neutral, while tribunnews.com tends to show the negative attitude towards Prabowo-Sandiaga[7].

\section{Conclusion}

From research-based learning many benefits can be learned. The benefits include (1) learning to be refreshing because it is not monotonous, (2) fostering passion in the learning situation, (3) students are actively involved, (4) lecturers get lots of input from students, and more especially because (5) framing analysis is relatively new applied in the Indonesian Literature study program[8], so that (6) increase students' insights about framing analysis, (7) the results of this study succeeded in changing the culture of learning, from what was originally passive in nature, only listened, and recorded to be active, creative, dynamic, critical, and exchanging arguments with each other. 


\section{References}

[1] Entman, R.M. Framing Bias: Media in the Distribution of Power. Journal of Communication, 57(1), 163-173 (2007)

[2] Bowen, S. A Framing Analysis of Media Coverage of the Rodney King Incident and Ferguson, Missouri, Conflicts. The Elon Journal of Undergraduate Research in Communications, 6(1), 114-124 (2015)

[3] Muhammad. Metode Penelitian Bahasa.Jakarta: AR-Ruzz Media.

Putera, Ghanes Eka. 2014. Bingkai Media Terhadap Pemberitaan Capres Jokowi Pada Pilpres 2014 (Analisis Framing Media Online Kompas.Com Dan Detik.Com). Semarang: Universitas Diponegoro. (2011)

[4] Eriyanto. Analisis Framing: Konstruksi, Ideologi, dan Politik Media (Cet.ke-3). Yogyakarta: LKIS. (2012)

[5] Muslih, Masnur. 2008. "Kekuasaan Media Massa Mengonstruksi Realitas". Jurnal Bahasa dan Seni tahun 36 no.2 Agustus 2008.

[6] Flora, Elina. Analisis Framing Berita Calon Presiden RI 2014 - 2019 Pada Surat Kabar Kaltim Post dan Tribun Kaltim. Kalimantan Timur: Universitas Mulawarman.(2014)

[7] Simbolon, Meydita. Kontruksi Berita dalam Media Massa (Analisis Framing Pemberitaan Dua Pasangan Calon Gubernur dan Wakil Gubernur DKI Jakarta "Jokowi-Basuki dan Fauzi-Nachrowi" dalam Majalah Tempo). Medan :Universitas Sumatera Utara. (2012)

[8] Hallahan, Kirk. Seven Models of Framing: Implication for Public Relations. Journal of Public Relation, 11(3), 205-242 (1999) 